\title{
Research on Advance of Rice False Smut Ustilaginoidea virens (Cooke) Takah Worldwide: Part I. Research Status of Rice False Smut
}

\author{
Shiwen Huang ${ }^{1,2}$, Lianmeng Liu ${ }^{1,3}$, Ling Wang ${ }^{1} \&$ Yuxuan Hou ${ }^{1}$ \\ ${ }^{1}$ State Key Laboratory of Rice Biology, China National Rice Research Institute, Hangzhou, China \\ ${ }^{2}$ Agricultural College, Guangxi University, Nanning, China \\ ${ }^{3}$ College of Plant Science and Technology, Huazhong Agricultural University, Wuhan, China \\ Correspondence: Shiwen Huang, State Key Laboratory of Rice Biology, China National Rice Research Institute, \\ Hangzhou 311401, Zhejiang, China. Tel: 86-133-8860-8130. E-mail: huangshiwen@caas.cn
}

Received: July 6, 2019 Accepted: August 9, $2019 \quad$ Online Published: September 15, 2019

doi:10.5539/jas.v11n15p240 URL: https://doi.org/10.5539/jas.v11n15p240

The research is financed by The key $R \& D$ project of Zhejiang province (2019C02018); The National Key $R \& D$

Projects of China (2018YFD0200304, 2016YFD0200801); Innovation project of CAAS (CAAS-ASTIP-2013-CNRRI); China-Norway international cooperation project: "CHN-2152, 14-0039 SINOGRAIN project II"; Shanghai municipality project "Agriculture through science and technology" (2019-02-08-00-08-F01127).

\begin{abstract}
Since hybrid rice was planted, rice false smut (RFS) caused by Ustilaginoidea virens (Cooke) Takah has risen from a sporadic secondary disease to a major devastating and common disease, due to the changes in climatic conditions, cultivation system, fertilization and water management and cultivar replacement, and has become one of the new three major rice diseases in China. In addition to cause rice yield decrease and economic losses, RFS also causes toxic effects on humans and animals, due to the fact that the pathogen has color, produces toxins, affects rice appearance, and reduces rice quality. Therefore, RFS has attracted great attention from various governmental agencies, research institutions and scientists. More than 300 papers related to RFS composed over the past 100 years were reviewed. In this part, the occurrence, epidemiology of RFS, the relationship between occurrence sverity of RFS and yield loss, field distribution pattern and sampling method of RFS and disease severity classification were discussed.
\end{abstract}

Keywords: rice false smut (RFS), occurrence and harm, Ustilaginoidea virens (Cooke) Takah, research progress

\section{Introduction}

\subsection{Importance of Rice and the Occurrence Status of RFS}

Rice is a staple food of more than half of the world's population, and more than $60 \%$ of the population of China. Increasing rice yield is thus crucial for solving problems of food shortage, ensuring food security, and reducing poverty (Yuan, 2014). Given that rice is a staple food of half the world's population, rice false smut (RFS) (Ustilaginoidea virens (Cooke) Takah) presents a constant threat to global food supplies. The development of durable and environment friendly strategies for the control of RFS depend on a better understanding of the developmental process of this pathogen, and the establishment of the disease (Hu et al., 2014).

RFS is a type of global rice heading stage fungal disease induced by Deuteromycotina Ustilaginoidea (U. virens (Cooke) Takah) (Tanaka et al., 2008a; Ashizawa et al., 2010; Kepler et al., 2012), and its main typical symptom is the formation of yellow to deep green RFS on the spikes of rice (false smut balls), commonly known as black ball disease, dustbrand or false smut (Suwa, 1915; Nakamura et al., 1992). RFS was recognized as a symbol of a bumper harvest and was categorized as a minor disease due to its sporadic occurrence (Ladhalakshmi, et al., 2012). Now, it is a serious disease of rice worldwide (Rush et al., 2000; Tsuda et al., 2006; Zhou et al., 2008; Brooks et al., 2009; Ladhalakshmi et al., 2012). It was called "bumper disease" or "good harvest fruit" in China. The pathogen of $U$. virens produces both sexual ascospores and asexual chlamydospores in its life cycle. In 
recent years, RFS has already become an important disease in rice producing areas in Asia, America, Aferica and Europe (Yaegashi et al., 1989; Brooks et al., 2009; Singh et al., 2010). False smut has become the main and serious rice disease since 2001 in India. The infected tillers were found to vary between $2 \%-85 \%$, the number of infected grains reached even more than 100 per panicle in severe cases. Due to the heavy false smut, the air above the infected field gave a black smoky appearance from a distance as a result of the release of spore mass in the atmosphere (Dodan, et al., 1996; Mandhare et al., 2008). In recent years, it has emerged as the most devastating grain disease in the majority of the rice-growing areas of the world including China (Wang et al., 2004), India (Ladhalakshmi et al., 2012), the United States (Brooks et al., 2009, 2010) and Japan (Tsuda et al., 2006; Ashizawa et al., 2011).

In China, RFS has a long history. Bencao Gangmu, written in the Ming Dynasty (1368-1644 AD), includes a description of "mildew grain of hard rice and slave rice" (i.e., false smut). However, RFS only occurred sporadically throughout a very long period of time, the damage was not severe, and the loss was small, thus it has been regarded as a minor disease of rice. Internationally, RFS, caused by the fungus $U$. virens (teleomorph: Villosiclava virens), was historically a minor rice disease (Padwick, 1950; Tanaka et al., 2008a). High-yield hybrid rice has been planted in large areas since the late 1970s, especially high yield varieties of Indica $\times$ japonica hybrid rice, and too much nitrogen fertilizer is topdressed at the tillering stage and booting stage. Especially in recent years, climate change and change of the farming system have led to increasingly serious cases of RFS in China, the occurrence of the disease displaying the characteristics of wide area, high frequency, and cuased severe yield losses (Pan et al., 1993; Wang et al., 2004; Zhou et al., 2008; Hou et al., 2009). At present, RFS is one of the three major diseases of rice in China, Table 1.

Table 1. Occurrence and control areas of main rice diseases between 2013 and 2015 in China (Thousand hectare, thousand ton)

\begin{tabular}{|c|c|c|c|c|c|c|}
\hline Diseases & Year & Ocurred area & Controlled area & Reduced yield loss & Actual yield loss & \\
\hline \multirow{3}{*}{ Total of diseases } & 2013 & 26807.49 & 52392.90 & 12468.30 & 1647.30 & \multirow{3}{*}{$\begin{array}{l}\text { If establish national level } \\
\text { post system expert }\end{array}$} \\
\hline & 2014 & 29935.80 & 59787.67 & 16082.00 & 2066.70 & \\
\hline & 2015 & 29439.40 & 59802.27 & 14904.60 & 1943.90 & \\
\hline & 2013 & 17448.97 & 25454.53 & 8279.70 & 1057.50 & \multirow{3}{*}{ Yes } \\
\hline \multirow[t]{3}{*}{ Rice sheath blight } & 2014 & 17878.67 & 28234.33 & 8728.00 & 1116.30 & \\
\hline & 2015 & 17934.13 & 27656.07 & 8152.40 & 1075.50 & \\
\hline & 2013 & 3679.18 & 12702.68 & 2247.90 & 318.7 & \multirow{3}{*}{ Yes } \\
\hline \multirow[t]{3}{*}{ Rice blast } & 2014 & 5136.20 & 16129.00 & 4632.10 & 558.30 & \\
\hline & 2015 & 5112.67 & 17150.67 & 4738.20 & 565.90 & \\
\hline & 2013 & 1995.30 & 5388.75 & 565.20 & 78.70 & \multirow{3}{*}{ No } \\
\hline \multirow[t]{3}{*}{ Rice false smut } & 2014 & 3154.73 & 7608.60 & 1011.80 & 189.10 & \\
\hline & 2015 & 3023.40 & 7779.20 & 919.20 & 161.10 & \\
\hline & 2013 & 573.26 & 2917.01 & 428.80 & 35.30 & \multirow{3}{*}{ Yes } \\
\hline \multirow[t]{2}{*}{ Rice virus diseases } & 2014 & 350.67 & 1357.47 & 247.10 & 19.40 & \\
\hline & 2015 & 267.87 & 1003.07 & 165.80 & 18.40 & \\
\hline
\end{tabular}

\subsection{Research Status of RFS}

"Rice and Ustilaginoidea", "Rice and Claviceps" and "Rice and Villosiclava" were used as the keywords to search in the "Web of Science", and 278, 64 and 23 records were respectively obtained (including patents), among which 182, 23 and 17 papers were published by Chinese scholars, accounting for $65.47 \%, 35.94 \%$ and $73.91 \%$, respectively, and an average of $58.44 \%$. From the quantity and quality of the published papers, the countries with greater numbers of and more in-depth studies on RFS, in order, are China, followed by Japan, the USA, India, and the International Rice Research Institute (IRRI, Philippines). "Rice and Ustilaginoidea" was used as the keyword in the "Web of Science" to search the contents between January 2013 and December 2014, including relevant papers and patents, and there was a total of 65 records, of which Chinese scholars published 56 papers (86.15\%), including 24 Chinese papers, 23 periodical English papers, and 9 patents; a total of 9 papers were published by other countries. Whether in terms of quantity or quality, the published papers on RFS by China occupy an absolute advantage. 
Jiang et al. (2012) used the full text database of Agricultural Science and Technology Periodical Literature in Chinese National Knowledge Infrastructure (CNKI) as the data source, using the bibliometric method, they counted and analyzed the published research papers on RFS by China for a period of more than 50 years (1957-2011) (Table 2).

Table 2. Published papers of RFS in China between 1957 and 2011

\begin{tabular}{llllll}
\hline Years & Before 1980 & Between 1980-1989 & Between 1990-1999 & Between 2000-2009 & Between 2001-2011 \\
\hline Number of Published papers & 4 & 155 & 398 & 1081 & 1242 \\
Average (papers/year) & $?$ & 15.5 & 39.8 & 108.1 & 112.9 \\
\hline
\end{tabular}

The Chinese keywords of "rice and RFS" were employed for retrieval (fuzzy matching) (time: January 1, 2012 to December 31,2014 ), and a total of 305 records were selected.

The related literatures of RFS in China were as early as in 1957 published in "Agricultural Science Communication" (which is limited to the retrieval system, and there may be earlier references). Before 1980, China's agricultural science and technology periodicals published a total of four papers related to RFS; between 1980 and 1989, 155 papers were published; between 1990 and 1999, there were 398 papers published, the document number of which is 2.6 times that of 1980-1989; between 2000 and 2009, a total of 1081 papers were published, 7.0 times of that of 1980-1989, and 2.7 times of that of 1990-1999. These related papers mainly included the contents such as disease investigation and chemical control. Currently, the selection and breeding of rice varieties resistance to RFS, genetic mechanism of disease resistance, and identification of resistance genes are relatively underdeveloped.

The present paper focuses on the analysis of a number of papers related to RFS and funding-supported project information over the period of 11 years (2001-2011) in China. There were 1242 papers related to Chinese RFS in 2001-2011. Before 2004, the papers related to RFS were published in 40 journals, and the number of published papers was less than 100. In 2005-2011, the annual average number of published papers related to RFS was greater than 100, and the papers were distributed in 40 journals. In 2001-2005, the number of published papers supported by projects was 27, among which 5 papers were supported by state-funded projects and 22 were supported by local projects. In 2006-2011, the number of published papers funded by projects was 77, of which 48 papers were supported by state-funded projects, and 29 by local projects. These data indicated that research on RFS in China carried out earlier, however, early research is relatively rare. After 2000, the number of papers related to RFS published in China increased rapidly, which may be related to the fact that the occurrence and damage of RFS have increased year by year, and more attention has been given to the research of RFS, funded by the relevant departments and strengthening of national project support.

\section{Occurrence and Damage and Economic Losses of RFS}

When the incidence rate of RFS is low, it has little effect on the yield of rice. The damage mainly includes the pathogenic fungus with color, toxic production, pollution of rice grains, reduction of rice quality, and toxicity to humans and animals. If occurrence of RFS is severe, it not only causes reduction of yield, pollutes rice grains and decreases the quality of rice, it also causes damage to consumers (Huang et al., 2003); Aside from the loss of production, false smut is also a threat to food safety as the chlamydospores of $U$. virens produce mycotoxins (Koiso et al., 1992; Miyazaki et al., 2009; Shan et al., 2012). The disease also causes economic losses to farmers due to a lower market price for their produce owing to the presence of black chlamydospores masses on healthy rice grains (Ladhalakshmi et al., 2012).

RFS is an intermittent occurrence disease in the past, nowadays, it has increased to be a main and common rice disease, especially in the single season rice and late rice. The infected panicle rate can reach as high as $30 \%$, and the incidence rate of grain reach $0.8 \%$ in the seriously diseased fields, which will result in a decreased maturing rate of seed, reduced 1000-grain weight, and yield loss rate of diseased panicle reach 11.5-54.5\% (Dong et al., 2003). 


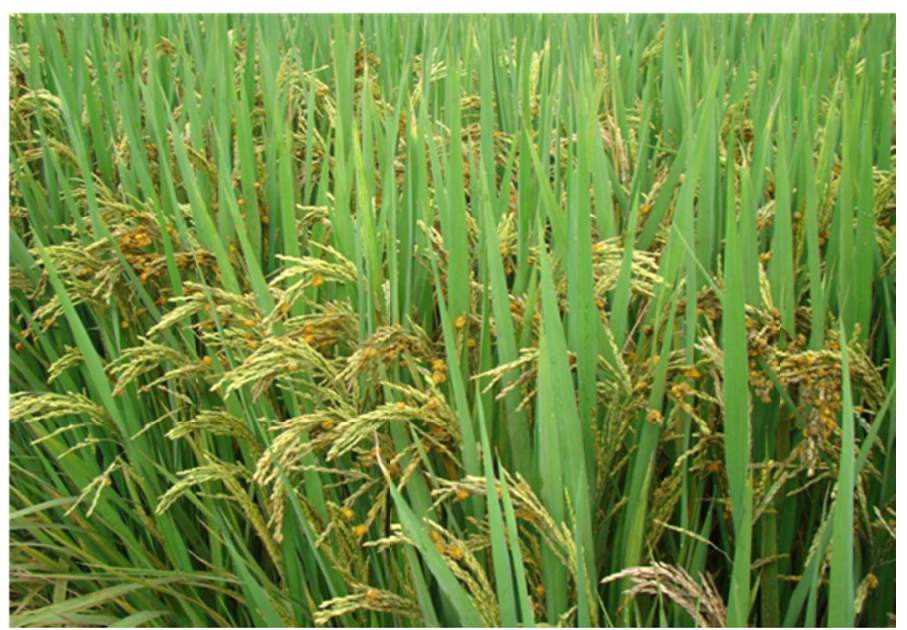

Figure 1. Seriously infected by U. virens of Yongyou 12, an indica/japonica hybrid rice combination

\subsection{Occurrence of RFS}

RFS was first reported by Cooke from Tirunelveli district of Tamil Nadu State of India, and named Ustilago virens (Cooke, 1878). In 1918, RFS occurred in large areas in the Philippines, occurred in Burma in 1945 and then was widespread in 1980. In 1975, the disease occurred in large parts of West Africa, and serious occurred in parts of India in 1992 (Wang et al., 2003). Thereafter, RFS has gradually spread, and now it is widely distributed throughout the world, including Asia, Africa, South and North America and Europe, to nearly 40 major rice production countries, such as China, India, Japan, the Philippines, Burma, Bangladesh, Australia, Brazil, Italy, the USA and Egypt, of which the spreading of RFS was quite serious in China, India, the Philippines, Japan and other Asian countries (Ou, 1985; Dodan et al., 1996; Atia, 2004; Xia et al., 2009; Ladhalakshmi et al., 2012). RFS was first reported in the 1930s and 1940s in some rice fields of the southern and the southwestern China, south of the Yangtze River and northeast China. In the 1950s and 1960s, RFS occurred sporadically in some parts of China. In the late 1970s, the disease showed a rising trend year by year, generally with large areas of planting of high-yield hybrid rice and increasing application of fertilizer level, but there were annual fluctuations. The occurrence and damage of RFS in China have become the third major disease, ranking only second to sheath blight (Rhizoctonia solani) and rice blast (Pyricularia oryzae).

\subsection{Damage Caused by RFS}

The damage of RFS has been investigated in a large area in various parts of China, while in other countries was not comprehensively investigated and reported. RFS was listed as the officially investigated rice disease by Ministry of Agriculture of P.R. China since 2009. In 2013-2014, the area of occurrence of RFS was 1995.3-3154.73 ha, and the yield loss of rice reached 643.90-1200.90 kilotons if without controlled (Table 1).

RFS is one of the important diseases currently constraining high quality and high yield of rice in $\mathrm{China}(\mathrm{Fu}$, 1994). In 1980, the occurrence area of RFS in Yunnan Province was only $6000 \mathrm{hm}^{2}$, by 1991 , the occurrence area of the disease was more than $60,000 \mathrm{hm}^{2}$, in 1993 , the areas reached $130,000 \mathrm{hm}^{2}$. The average rate of diseased panicle was 3-5\%, while the infected rate of panicle was as high as $40 \%$ in severely infected rice fields (Liao et al., 1994). The occurrence area of RFS was more than $600,000 \mathrm{hm}^{2}$ in Jiangxi province in 1982, and it caused 30 million $\mathrm{kg}$ yield loss of rice (Ji et al., 1995). In 1980-1982, there were more than 340,000 $\mathrm{kg}$ of rice grain loss because of RFS in a town in Fenghua county of Zhejiang province. In 1984-1986, the infected rice area by RFS in Liaoning province increased from $200,000 \mathrm{hm}^{2}$ to $330,000 \mathrm{hm}^{2}$, showing a rising trend year by year. In 1986, the occurrence area of RFS in Funing, Luannan and Tanghai counties of Hebei province was only $212,000 \mathrm{hm}^{2}$, while in 1987 and 1988, the infected area increased to $360,000 \mathrm{hm}^{2}$ and more than $500,000 \mathrm{hm}^{2}$. Even more serious, nearly more than $70 \%$ of the paddy fields were infected by RFS in varying degrees in 1989 . In 1990, the diseased area of RFS in Mengzi county of Yunnan province reached more than $65.8 \%$ ( $\mathrm{Li}$ et al., 2006). In 1994, RFS occurred in 70,000 $\mathrm{hm}^{2}$ of rice fields in eastern Hebei province, and caused 37.2 million $\mathrm{kg}$ loss of rice grain (Pan et al., 1997a, 1997b). In 1984, the occurrence area of RFS in Liaoning province was about $200,000 \mathrm{hm}^{2}$, accounting for $43 \%$ of all the planting area of rice in the province. The rate of diseased panicle was generally $5-10 \%$, and more than $30 \%$ in serious plots. In 1996, the disease occurrence area has increased to 
$330,000 \mathrm{hm}^{2}(\mathrm{Ji}, 2002)$. RFS was first discovered in Heilongjiang province in 1986, at present, the disease has become one of the main rice diseases in the local (Gao et al., 2001).

In 1982, the occurrence of RFS in Hunan province was serious, the infected rice area was about $670,000 \mathrm{hm}^{2}$, and there were $75.4 \%$ areas were seriously infected among the diseased fileds (Ji et al., 1995). In 2003, an area of more than $233,000 \mathrm{hm}^{2}$ had infected by RFS, and the loss was nearly 100 million $\mathrm{kg}$. In 2004, there was false smut disease with different degrees in various counties, states and cities throughout Hunan province. The infected area was $633,000 \mathrm{hm}^{2}$, the loss of rice was 137 million $\mathrm{kg}$, and the direct economic loss was 200 million RMB yuan (Wang et al., 2005). The area with a diseased panicle rate of less than $10 \%$ accounted for $46.75 \%$; that with a diseased panicle rate of $10 \%-20 \%$ accounted for $24.5 \%$; that with a diseased panicle rate of $20 \%-40 \%$ accounted for $15.5 \%$; that with a diseased panicle rate of more than $40 \%$ accounted for $3.75 \%$; the diseased panicle rate reached $80 \%$ in the most seriously infected field, and there was only $9.5 \%$ of rice areas not be infected. In general, the number of diseased grains was 5-10 grains per panicle, however, at the seriously infected panicle, there were about 15-20 diseased grains per panicle (Zhang et al., 2009). In 2005, the RFS occurrence area throughout the province was nearly $266,700 \mathrm{hm}^{2}$, and the loss of rice was 100 million $\mathrm{kg}$. According to incomplete statistics, the area with occurrence of RFS of middle and late rice in Hunan province in 2003-2005 was more than one million $\mathrm{hm}^{2}$, and the direct economic loss was 200 million RMB yuan. RFS mainly harms double-cropping late rice, followed by one season of middle and late rice in Hunan province, and the early rice generally has a lower incidence. The panicle maturation rate, brown rice rate, polished rice rate and head rice rate of the panicle which infected with RFS all decreased, while the rate of green rice and death rice rate increased significantly (Hou et al., 2009).

In 2004, RFS universally occurred in one-season middle rice in Changde city of Hunan province, covering an area of $40,000 \mathrm{hm}^{2}$, and accounting for $31.9 \%$ of the total sown area of $125,300 \mathrm{hm}^{2}$, which is rare in the past 10 years. The rice yield loss caused by RFS was 12.63 million $\mathrm{kg}$, of which there was $1.09 \mathrm{hm}^{2}$ of Honglianyou No. 6 and $1.68 \mathrm{hm}^{2}$ Yueyou 938, with a yield reduction of $70 \%$; there was $1.41 \mathrm{hm}^{2}$ of II You 084, with a reduction of $50 \%$; and there was $1.41 \mathrm{hm}^{2}$ of Liangyoupeijiu (LYPJ), with a reduction of $40 \%$ (Liu et al., 2006). In 2005, RFS generally occurred in the middle and late rice of Zhenba county in Shaanxi province, and was especially serious in the late rice. There were $4433 \mathrm{hm}^{2}$ rice fields were moderate to seriously infected by RFS throughout all of Zhenba county, the average yield loss was $407.4 \mathrm{~kg}$ per hectare, and the direct loss of rice was 1.81 million $\mathrm{kg}$, of which the area with a diseased panicle rate of $8-43 \%$ was $3500 \mathrm{hm}^{2}$, with an average yield loss of $662.4 \mathrm{~kg}$ per hectare, and the area with a diseased panicle rate of less than $8 \%$ was $933 \mathrm{hm}^{2}$, with average yield loss of $197.4 \mathrm{~kg}$ per hectare. The direct economic loss was 1.26 million RMB yuan (Lu et al., 2006). In 2008, the area of RFS in Anhui province was more than 500,000 $\mathrm{hm}^{2}$ (Lv et al., 2008).

In India, it was reported that RFS caused the resistant and susceptible rice varieties' yield loss from $2.0 \%-12.9 \%$; grain filling decrease from 3.28\%-19.27\%; 1000-grain weight decrease from 4.93-21.84\%. Germination percentage of seeds were reduction of most rice cultivars, $19.43 \%$ reduction in seedling length and $22.79 \%$ decrease in vigour index (Srivastava et al., 2014).

\section{Field Distribution and Disease Classification of RFS}

\subsection{Field Distribution Pattern and Sampling Method of RFS}

It is generally believed that the distribution type of RFS in the field is the aggregated distribution, but there are differences among the varieties and degree of incidence of diseases. Tang et al. (1998) believed that the diseased rice panicle of RFS and the diseased grain exhibited aggregated distribution in the field, and the reason for aggregation was induced by environmental factors. Therefore, the investigation of RFS in fields should use the parallel sampling method, which is the most suitable. Li (1995) employed different varieties of rice for experiments, and found that the field distribution type of RFS conformed to the negative binomial distribution, but it conformed to both the negative binomial distribution and Neyman distribution in mild cases. The sampling accuracy of the two-parallel linear jump methods in the field investigation is the highest, followed by the diagonal line, and the suitable sampling number in each region is 200 hills. Pan et al. (1998) researched and believed that both the distributions of the diseased panicle of RFS and diseased grain are aggregated (negative binomial) distributions, and the basic component of the distribution was the loose individual group, and the distribution in individual group was random. The individual population ranges of the diseased panicle and diseased grain were 4-8 and 2-4 clusters, respectively. Sun et al. (2006) believed that the distribution of the diseased grain was the aggregation distribution, but the distribution types of the different varieties were different. The diseased panicle distributions of "Yueyou 938" and "Wuyunjing" were the uniform type, and the diseased panicle distributions of "W9707" and "Taihu rice" were the aggregation types. Xiao et al. (2007) conducted a 
large area of investigations in the maturity period of the late rice variety, and concluded that the field distribution of RFS belonged to the Neyman distribution type of the aggregation distribution through theoretical frequency calculation and tests of goodness of fit of various distribution types, and the parallel jumping sampling method was the field survey method most suitable for the disease. For the highly susceptible cultivar, RFS spatial distribution in the fields conform to nonrandomness aggregation. The best way for sampling survey of RFS in the field was parallel and saccad sampling (Xie et al., 2019).

\subsection{Relationship Between Occurrence Degree of RFS and Yield Loss}

In addition to the lesions of grains, the loss of rice yield caused by RFS mainly leads to the decrease of the actual grain number of the whole rice grains, 1000-grain weight and single grain weight. Research has shown that there is an extremely significant negative correlation between the number of the diseased grain per panicle and elements of rice yield. There was a significant positive correlation between the percentage of empty grain and the number of diseased grains per panicle, with a correlation coefficient of $r=0.9886$. One diseased grain per rice panicle is increased, and the empty grain rate is increased by $3.5 \%$, while the single panicle weight is decreased by $0.14 \mathrm{~g}$. The correlation coefficient between single panicle weight and diseased grain number per rice panicle was $r=-0.9913$. One diseased grain is increased per panicle, and the loss rate of average per panicle weight is increased by $6.1 \%$, of which one diseased grain caused weight loss of per panicle was $9.3 \%$, and 9 diseased grain caused the weight loss of per panicle was $48.2 \%$, with an average value of $30.3 \%$. The effect of the number of diseased grains per panicle on 1000-grain weight is not significant, at $r=0.5958$. The increased diseased rice grain of RFS and degree of the decreased grain weight of single panicle was different between varieties (Huang et al., 1988). Zou et al. (1994) analyzed the relationship between RFS and the yield loss by using the grey correlation degree method, and they pointed out that the decline of the setting percentage was the main reason for yield loss of rice. There was a significant negative correlation between the number of the diseased grains of RFS per panicle and 1000-grain weight and grain number per panicle and panicle weight (the correlation coefficients were $-0.9663,-0.9036$ and -0.9723 ), and it was significant positively correlated with the immature grain rate (correlation coefficient: +0.8965 ) (Shi et al., 2003). Gao et al. (2001) believed that there was a significant linear correlation among the number of diseased grains per panicle of RFS and empty grain rate, 1000-grain weight and yield loss rate. According to the control and treatment cost and price of rice and other factors, the economic threshold of RFS was obtained. Japonica rice "9516" had 1-10 diseased grains per panicle, and the percentage of empty grain was in the range of $14.26-50.19 \%$, and the 1000 -grain weight was $26.3-21.8 \mathrm{~g}$, and rate of yield loss was $2.79-54.88 \%$. Indica hybrid rice "R405" had 1-10 diseased grains per panicle, the percentage of empty grain was in the range of $29.12-44.22 \%$, the 1000 -grain weight was $25.0-22.0 \mathrm{~g}$, and the rate of yield loss was 7.64-36.22\%. The effects of increasing one diseased grain per panicle on the percentage of empty grain, 1000-grain weight and yield loss rate on Japonica rice "9516" were greater than those of indica hybrid rice "R405". Jiang et al. (2009) and Yang et al. (2013) also believed that the presence of diseased grain strongly influenced the 1000-grain weight of health grain which close to the spindle panicle, and the empty grain rate of the diseased panicle was increased, and the 1000-grain weight was decreased, ultimately affecting the yield of rice. Ding et al. (1997) established the Weibull model of rice of the number of diseased grains per panicle, reduction rate of rice yield and the rate of decline of milled rice. Wang et al. (2007) used the statistical software of SAS to analyze the field data, and they pointed out that the main factors affecting the rice yield were the rate of diseased panicle of RFS, followed by the rate of diseased grain, and the rate of infected hill was the secondary factor.

\subsection{Disease Severity Classifications of RFS}

The relationship between the degree of the occurrence of RFS and yield loss of rice is significantly different because of different varieties, and the results of different researchers. According to the differences of degree of RFS, disease index or damage loss index, the degrees of occurrence of RFS were divided into multiple levels, but yet there is no unified classification standard. Li (1996) divided the diseases into 10 grades according to the percentage of the diseased grain number in the total number of grains of each panicle, which are as follows: scales 0 , no obvious symptoms (none diseased grain of RFS in the panicle); scales 1-9, the percentages of the diseased grain in the total grain number per panicle were $0.1-2 \%, 2.1-5.0 \%, 5.1-10.0 \%, 10.1-15.0 \%, 15.1-20.0 \%$, $20.1-30.0 \%, 30.1-50.0 \%, 50.1-75.0 \%$, and more than $75.1 \%$, respectively. Tang et al. (2000) employed Q type systematic cluster analysis, and they used five indicators of aspect ratio of false smut ball (FSB), weight of 100 -grain FSB, filled grain weight per panicle, seed setting rate, and loss rate for the classification of the number of the RFS diseases, and the RFS was divided into six levels according to the numbers of FSB in a panicle: Level 0 , no diseased grain; Level 1, 1 grain of false smut ball; Level 2, 2 grains of false smut ball (chlamydospore); Level 3, 3-5 grains of false smut ball; Level 4, 6-9 grains of false smut ball; and Level 5, more than 10 false smut 
ball. Shi et al. (2003) used the loss rate of panicle weight as the index, and they divided the RFS disease into six grades: scale 0 , panicle weight loss rate 0 ; Grade 1 , panicle weight loss rate $\leq 5 \%$; Grade 2 , panicle weight loss rate $\leq 10 \%$; scale 3 , panicle weight loss rate $\leq 20 \%$; scale 4 , panicle weight loss rate $\leq 50 \%$; and scale 5 , panicle weight loss rate more than 50\%. Li et al. (2011) studied and concluded that the regression equation of yield loss rate caused by RFS and the average grain number per panicle was $y=2.8624 \mathrm{x}+0.5427(\mathrm{P}=0.0001)$, and they divided the severity of RFS into six scale with a more accurate average grain number per panicle and yield loss rate. Some of the above classification standards were complex to a certain degree, and some standards were too fine to be determined rapidly, thus it was difficult to implement in the field investigation operation.

Zhang et al. (2006) reference grading standard of rice neck blast (Pyricularia oryzae) incidence to differentiate the resistance or susceptible of rice varieties to RFS. The grading standards are as follows: Level 0: diseased panicle rate less than or equal to $1 \%(\mathrm{HR})$; Level 1: $1 \%<$ diseased panicle rate $\leq 5 \%(\mathrm{R})$; Level $3: 5 \%<$ diseased panicle rate $\leq 10 \%$ (MR); Level 5: $10 \%<$ diseased panicle rate $\leq 25 \%$ (MS); Level 7: $25.0 \%<$ diseased panicle rate $\leq 50 \%(\mathrm{~S})$; and Level 9: diseased panicle rate $>50.1 \%$ (HS). Deng (1989) divided the RFS disease severity into six levels according to the number of false smut ball in a single panicle: scale 0 , no diseased grain; scale 1, 1 false smut ball; scale 2, 2-5 false smut balls; scale 3, 6-10 false smut balls; Grade 4, 11-15 false smut balls; and scale 5, more than 16 false smut balls. The above two grade standards are too rough for practical purposes, and thus cannot reflect the incidence of RFS and actual output loss.

Disease resistance levels are usually conducted on domestic RFS according to the infected hill rate, diseased panicle rate, number of diseased grains per panicle, diseased grain rate of a panicle, and panicle weight loss rate, then the disease index is calculated. Shiwen Huang (professional standard, 2019) set the classification standard by combining the standards of different researchers, taking into account the current rice varieties and occurrence of RFS, harm and toxins and other factors, and he personally believe that this grading standard is quite scientific and reasonable. Table 3 shows the grading standard of RFS currently used in China and give the commentary of each grading standard.

Table 3. Disease index grading standard of RFS and their merit and demerit

\begin{tabular}{|c|c|c|c|c|c|c|c|c|}
\hline & Disease scale & 0 & 1 & 3 & 5 & 7 & 9 & \multirow{2}{*}{ Commentary } \\
\hline & Resistance & HR & $\mathrm{R}$ & MR & MS & $\mathrm{S}$ & HS & \\
\hline Chen Jiafu et al. & Infected panicle rate $(\%)$ & 0 & $0.1-5.0$ & $5.1-10.0$ & $10.1-25.0$ & $25.1-50.0$ & $\geq 50.1$ & $\begin{array}{l}\text { Easy to operate, } \\
\text { but low accuracy }\end{array}$ \\
\hline \multirow[b]{2}{*}{$\begin{array}{l}\text { Zhang Yushu et al. } \\
\text { (1992) }\end{array}$} & Infected grains per panicle & 0 & 1 & 2 & $3-6$ & $7-10$ & $\geq 11$ & \multirow{2}{*}{$\begin{array}{l}\text { The former is easy to operate } \\
\text { and basically reasonable; the } \\
\text { later is difficult to operate }\end{array}$} \\
\hline & $\begin{array}{l}\text { Weight loss rate } \\
\text { per panicle }(\%)\end{array}$ & 0 & $0.1-5.0$ & $5.1-10.0$ & $10.1-20.0$ & $20.1-50.0$ & $\geq 50.1$ & \\
\hline \multirow[b]{2}{*}{ Li Xian (1996) } & infected grains per panicle & 0 & $1-2$ & 3 & $4-5$ & $6-7$ & $8-9$ & \multirow{2}{*}{$\begin{array}{l}\text { The former is easy to operate } \\
\text { and basically reasonable; the } \\
\text { later is difficult to operate }\end{array}$} \\
\hline & Infected grain rate $(\%)$ & 0 & $0.1-5.0$ & $5.1-10.0$ & $10.1-20.0$ & $20.1-50$ & $\geq 50.1$ & \\
\hline $\begin{array}{l}\text { Liu Yongfeng et al. } \\
(2000)\end{array}$ & Infected grains per panicle & 0 & 1 & $2-4$ & $5-7$ & $8-10$ & $>11$ & $\begin{array}{l}\text { Easy to operate, } \\
\text { Basically reasonable }\end{array}$ \\
\hline \multirow{2}{*}{$\begin{array}{l}\text { Shi Chenzhi et al. } \\
(2003)\end{array}$} & Infected grains per panicle & 0 & 1 & $2-3$ & $4-7$ & $8-15$ & $\geq 16$ & \multirow{2}{*}{$\begin{array}{l}\text { The former basically } \\
\text { reasonable and easy to } \\
\text { operate; the later is } \\
\text { difficult to operate }\end{array}$} \\
\hline & $\begin{array}{l}\text { Weight loss rate } \\
\text { per panicle }(\%)\end{array}$ & 0 & $0.1-5.0$ & $5.1-10.0$ & $10.1-20.0$ & $20.1-50.0$ & $\geq 50.1$ & \\
\hline $\begin{array}{l}\text { Zhang Juncheng et al. } \\
\text { (2004) }\end{array}$ & $\begin{array}{l}\text { Infected grain rate } \\
\text { per panicle }(\%)\end{array}$ & 0 & $0<\mathrm{X} \leq 2$ & $2<X \leq 5$ & $5<X \leq 10$ & $10<X \leq 20$ & $20<X$ & $\begin{array}{l}\text { Heavy workload for } \\
\text { investigation and evaluation }\end{array}$ \\
\hline Zhang Shu et al. & Infected panicle rate $(\%)$ & $<1$ & $1.0-5.0$ & $5.1-10.0$ & $10.1-25.0$ & $25.1-50.0$ & $\geq 50.1$ & $\begin{array}{l}\text { Easy to operate, } \\
\text { but low accuracy }\end{array}$ \\
\hline \multirow{2}{*}{$\begin{array}{l}\text { Huang Shiwen } \\
\text { (professional standard } \\
\text { of China, 2019) }\end{array}$} & Infected grains per panicle & 0 & 1 & $2-4$ & $5-8$ & $9-15$ & $\geq 16$ & \multirow{2}{*}{$\begin{array}{l}\text { The former is scientific } \\
\text { and reasonable and easy to } \\
\text { operate; the later is difficult } \\
\text { to operate }\end{array}$} \\
\hline & $\begin{array}{l}\text { Weight loss rate } \\
\text { per panicle }(\%)\end{array}$ & 0 & $0.1-5.0$ & $5.1-10.0$ & $10.1-20.0$ & $20.1-50.0$ & $\geq 50.1$ & \\
\hline
\end{tabular}

Note. Disease index $=[\Sigma$ (number of diseased plants $\times$ representative value of disease grade)/total number of investigated plants $\times$ highest representative value of disease grade] $\times 100 \%$; diseased panicle rate $(\%)=$ (diseased panicle number/total surveyed panicle number $) \times 100 \%$; panicle weight loss $(\%)=($ diseased panicle weight/panicle weight without diseases) $\times 100 \%$. 


\section{References}

Ashizawa, T., Takahashi, M., Moriwaki, J., \& Hirayae, K. (2010). Quantification of the rice false smut pathogen Ustilaginoidea virens from soil in Japan using real-time PCR. Eur J Plant Pathol, 128(2), 221-232. https://doi.org/10.1007/s10658 -010-9647-4

Ashizawa, T., Takahashi, M., Moriwaki, J., \& Hirayae, K. (2011). A refined inoculation method to evaluate false smut resistance in rice. J Gen Plant Pathol (Fungal Diseases), 77, 10-16. https://doi.org/10.1007/ s10327-010-0279-5

Atia, M. M. M. (2004). Rice false smut (Ustilaginoidea virens) in Egipt. Zeitschrift fur Pflanzenkrankheiten and Pflanzenaschutz, 1, 71-82. https://doi.org/10.1007/BF03356134

Brooks, S. A., Anders, M. M., \& Yeater, K. M. (2009). Effect of cultural management practices on the severity of false smut and kernel smut of rice. Plant Disease, 93(11), 1202-1208. https://doi.org/10.1094/ PDIS-93-11-1202

Brooks, S. A., Anders, M. M., \& Yeater, K. M. (2010). Effect of furrow irrigation on the severity of false smut in susceptible rice varieties. Plant Disease, 94(5), 570-574. https://doi.org/10.1094/PDIS-94-5-0570

Chen, J., Deng, G., Yang, Z., \& Liu, Z. (1992). Studies on resistance identification of rice germplasm resources to rice false smut. Chinese Seed Industry, 2, 35-36.

Cooke, M. C. (1878). Some extra European fungi. Grevillea, 7, 13-15.

Deng, G. (1989). Studies on grading standard of rice false smut. Shannxi Agri Sci, 4, 23-25.

Ding, K., Tan, G., Hu, J., \& Zhou, S. (1997). Yield loss of rice damaged by rice false smut. Plant Protection, 23(1), 3-6.

Dodan, D. S., \& Singh, R. (1996). Recent advances in research on cowpea diseases. Present Status Agri Rev, 17(4).

Dong, H., Qian, J., Xu, G., \& Zhang, Q. (2003). Measurement of rice false smut (Ustilaginoidea virens) caused japonica rice yield loss. Zhejiang Agri Sci, 2, 85-86.

$\mathrm{Fu}, \mathrm{X}$. (1994). The review of solving the damage of rice green smut in Jilin province using and selecting resistance cultivar. Jilin Agri Sci, 4, 27-29.

Gao, J., Xi, B., Wu, Y., Wu, T., Wang, D., \& Zhao, Y. (2001). First exploration of yield loss caused by rice false smut and its economic threshold. Jiangsu Agri Sci, 3, 36-37.

Hou, X., Li, Y., Wei, Z. S., \& Hou, Z. (2009). Investigation and analysis of the occurrence and damage of rice false smut in Hunan province. Hunan Agri Sci, 9, 87-88.

Hu, M., Luo, L., Wang, S., Liu, Y., \& Li, J. (2014). Infection processes of Ustilaginoidea virens during artificial inoculation of rice panicles. Eur J Plant Pathol, 139, 67-77. https://doi.org/10.1007/s10658-013-0364-7

Huang, S., \& Yu, L. (2003). Rice varieties (combinations) and the occurrence and management of rice false smut. China Rice, 10(4), 32-33.

Huang, Y., \& Hu, W. (1988). Effect on the yield loss of rice false smut. Plant Protection, 14(5), 43

Ji, H., \& Zhen, H. (1995). Research status of rice false smut (Ustilaginoidea virens) in China. Heilongjiang Agri Sci, 5, 40-41.

Ji, H. (2002). Advances in study on false smut of rice. Heilongjiang Agri Sci, 4, 34-37.

Jiang, P., Feng, W., Chen, J., \& Yan, Y. (2012). Analysis of the research status of rice false smut in recent ten-year in China base on bibliometric method. Service of Agri Tech, 29(6), 756-764.

Jiang, Z., Jiang, Z. C., Jiang, Z., \& Zhang, G. (2009). Effect of false smut ball number on yield of rice. North Rice, 39(3), 53-54.

Kepler, R. M., Sung, G. H., Harada, Y., Tanaka, K., Tanaka, E., Hosoya, T., ... Spatafora, J. W. (2012). Host jumping onto close relatives and across kingdoms by Tyrannicordyceps (Clavicipitaceae) gen. nov. and Ustilaginoidea (Clavicipitaceae). Am J Bot, 99, 552-561. https://doi.org/10.3732/ajb.1100124

Koiso, Y., Natori, M., Iwasaki, S., Sato, S., Sonoda, R., Fujita, Y., ... Sato, Z. (1992). Ustiloxin A: A phytotoxin and a mycotoxin from false smut balls on rice panicles. Tetrahedron Letters, 33(29), 4157-4160. https://doi.org/10.1016/S0040-4039(00)74677-6 
Ladhalakshmi, D., Laha, G. S., Singh, R., Karthikeyan, A., Mangrauthia, S. K., Sundaram, R. M., ... Viraktamath, B. C. (2012). Isolation and characterization of Ustilaginoidea virens and survey of false smut disease of rice in India. Phytoparasitica, 40(2), 171-176. https://doi.org/10.1007/s12600-011-0214-0

Li, M. (1995). Analysis of paddy field distribution and sampling technology of rice false smut. Fujian Rice and Wheat Sci \& Tech, 13(2), 37-42.

$\mathrm{Li}, \mathrm{X}$. (1996). Rice false smut control by seeds treating with chemicals and identification of rice varieties' resistance to Ustilaginoidea virens. J of Anhui Agri Sci, 24(3), 245-246.

Li, X., Liu, E., Xiao, Q., Su, S., \& Zhao, Z. (2006). Advances on studies about false smut of rice. Agrochenmicals Research \& Application, 10(3), 9-12.

Li, X., Liu, E., Xiao, Q., Liu, N., Wang, J., Tan, X., \& Zheng, H. (2011). Rating of rice resistance against Ustilaginoidea virens and relationship between resistance and yield loss. J of Hunan Agri Univ (Natural Sci), 37(3), 275-279. https://doi.org/10.3724/SP.J.1238.2011.00275

Liao, Q., \& Li, H. (1994). Research progress of rice false smut (Ustilaginoidea virens) in Yunnan province. Yunnan Agri Sci and Tech, 3, 8-10.

Liu, K., Wu, P., \& Wu, Y. (2006). Analysis of occurrence causes and control measures of rice false smut (Ustilaginoidea virens) in Changde city. Hunan Agri Sci, 1, 57-58.

Liu, Y., Lu, F., Chen, Z., Li, Y., \& Yu, Y. (2000). Evaluation of resistance to rice false smut of major cultivars and reserve varieties in Jiangsu province. Crop Journal, 6, 11-13.

Lu, H., Li, C., \& Yang, J. (2006). Simple analysis of epidemic reasons for rice false smut (Ustilaginoidea virens) in Zhenba county Shannxi province in 2005. Shannxi Agri Sci, 2, 76-106.

Lv, B., Luo, H., Zahng, Q., Wang, S., \& Huang, J. (2008). Research progress for rice false smut (Ustilaginoidea virens). Hubei Plant Protection, F06, 47-48.

Mandhare, V. K., Gawade, S. B., Game, B. C., \& Padule, D. N. (2008). Prevalence and incidence of bunt and false smut in paddy (Oryza sativa L.) seeds in Maharastra. Agri Sci Digest, 28, 292-294.

Miyazaki, S., Matsumoto, Y., Uchihara, T., \& Morimoto, K. (2009). High-performance liquid chromatographic determination of ustiloxin A in forage rice silage. $J$ of Veterinary Medical Sci, 71(2), 239-241. https://doi.org/10.1292/jvms.71.239

Nakamura, K. I., Izumiyama, N., Ohtsubo, K., Koiso, Y., Iwasaki, S., Sonoda, R., ... Sato, Z. (1992). Lupinosis in rice caused by ustiloxin and a crude extract of fungal culture of Ustilaginoidea virens. Proc Jpn Assoc Mycotoxicol, 35, 41-43. https://doi.org/10.2520/myco1975.1992.41

Ou, S. H. (1985). False Smut (Green Smut). In S. H. Ou (Ed.), Rice disease (2nd ed., pp. 307-311). Commonwealth Mycology Institute, Famham Royal, UK.

Padwick, G. W. (1950). Manual of Rice Diseases (pp. 88-92). Kew, UK: London: Commonwealth Mycological Institute, CAB Press.

Pan, X., \& Li, K. (1997a). Effect of total nitrogen fertilizer, dosage of panicle fertilizer and application period of earing fertilizer on the occurrence degree of to rice false smut (Ustilaginoidea virens). Hebei Agri Reclamation Sci \& Tech, 2, 6-9.

Pan, X., Li, K., \& Zhang, S. (1997b). Studies on the relationship between occurrence degree of rice false smut (Ustilaginoidea virens) and meteorological factors. Hebei Agri Reclamation Sci \& Tech, 2, 9-12.

Pan, X., Zhang, S., Gao, J., \& Zhang, X. (1993). Effect of nitrogen and phosphatic fertilizer on the occurrence degree of rice false smut (Ustilaginoidea virens). Hebei Agri Sci, 1, 18-20.

Pan, Y., \& Wu, H. (1998). Spatial distribution patterns of diseased panicle and diseased grain of rice green smut (Ustilaginoidea virens). J of Nanjing Agri Univ, 21(3), 41-46.

Rush, M. C., Shahjahan, A. K. M., Jones, J. P., \& Groth, D. E. (2000). Outbreak of false smut of rice in Louisiana. Plant Disease, 84(1), 100. https://doi.org/10.1094/PDIS.2000.84.1.100D

Shan, T. J., Sun, W. B., Liu, H., Gao, S., Lu, S. Q., \& Wang, M. G. (2012). Determination and analysis of Ustiloxins A and B by LC-ESI-MS and HPLC in false smut balls of rice. International J of Molecular Sci, 13(9), 11275-11287. https://doi.org/10.3390/ijms130911275 
Shi, C., Guo, Y., Lu, B., \& Gan, H. (2003). Divided standards of rice false smut (RFS) and initial measurement of output loss due to RFS. J of Shanghai Jiaotong Univ (Agri Sci), 21(2), 152-155.

Singh, A. K., \& Pophaly, D. J. (2010). An unusual rice false smut epidemic reported in Raigarh District, Chhattisgarh, India. International Rice Research Notes, 35, 1-3.

Srivastava, J. P., Maurya, D. K., \& Kushwaha, G. D. (2014). Effect of false smut (Ustilaginoidea virens) on seed yield and quality attribute in rice varieties. Agric Biol Res, 30(2), 196-200.

Sun, X., Tao, C., Cheng, S., \& Zhou, M. (2006). Studies on the spatial distribution type and damage and loss rate testing caused by rice false smut (Ustilaginoidea virens). Anhui Agri Sci Bul1, 12(6), 197-198.

Suwa, M. (1915). Study on Ina-kouji Part 1. JAMAS (Igaku Chuo Zasshi, Japan), 13, 661-689.

Tanaka, E., Ashizawa, K., Sonoda, R., \& Tanaka, C. (2008). Villosiclava virens gen. nov., comb. nov., teleomorph of Ustilaginoidea virens, the causal agent of rice false smut. Mycotaxon, 106(1), 491-501.

Tang, C., Jiang, M., Gao, J., Cao, G., Liu, C., Xie, W., ... Tang, C. (1998). Studies on the spatial distribution type and sampling technique of rice false smut of two-line hybrid rice. Hunan Agri Sci, 5, 38-41.

Tang, C., Gao, J., Cao, G., Huang, S., Liu, E., Liu, C., ... Xiao, Q. (2000). Research and applicationof classification standard of rice fa1se smut. J of Hunan Agri Univ, 26(2), 122-124.

Tsuda, M., Sasahara, M., Ohara, T., \& Kato, S. (2006). Optimal application timing of simeconazole granules for control of rice kernel smut and false smut. J Gen Plant Pathol, 72, 301-304. https://doi.org/ $10.1007 / \mathrm{s} 10327-006-0288-6$

Wang, D., Dong, H., Yang, H., Xu, W., \& Liu, F. (2003). Preliminary report of several fungicides control effect on rice false smut. Liaoning Agri Sci, 5, 47-48.

Wang, D., Wang, S., \& Fu, J. (2004). Research advance on false smut of rice. Liaoning Agri Sci, 1, 21-4.

Wang, G., \& Li, G. (1990). Artificial culture method of rice false smut pathogen (Ustilaginoidea virens). Acta Phytopathologica Sinica, 20(1), 32.

Wang, M., \& Zhou, Y. (2007). Correlation between rice yield and the occurrence level of rice false smut. $J$ of Xinjiang Agri Univ, 30(4), 76-79.

Wang, J., \& Chen, Y. (2005). Investigation of epidemiology of rice false smut in middle and late rice in 2004 in Hunan province. China Plant Protection, 25(8), 14-15.

Xia, B., \& Wang, L. (2009). Study status of rice false smut (Ustilaginoidea virens) in China. Animal Husbandry and Feed Science, 30(1), 33-34.

Xiao, Y., Liu, E., \& Li, X. (2007). Preliminary report of studing for field distribution and sampling method of rice false smut. Crop Research, 1, 38-40.

Xie, Z., Fang, H., Li, Y., Xu, W., Chen, H., \& Huang, S. (2019). Spatial distribution and sampling technique of rice false smut (RFS) in indica/japonica hybrind rice. Plant Protection, 45(2), 134-137. https://doi.org/ 16688/j.zwbh.2018195

Yaegashi, H., \& Fujita, S. R. (1989). Severe outbreak of false smut of rice in 1988. Plant Protection Tokyo, 43(6), 311-314.

Yang, X., Lin, T., Ruan, H., Shi, N., Du, Y., Gan, L., \& Chen, F. (2013). Effect of false smut on yield of rice and disease resistance detection of new rice varieties. Chinese $J$ of Tropical Crop, 34(7), 1309-131. https://doi.org/10.3969/i.issn.1000-2561.2013.07.020

Yuan, L. P. (2014). Development of hybrid rice to ensure food security. Rice Science, 1, 1-2. https://doi.org/ 10.1016/S1672-6308(13)60167-5

Zhang, J., Chen, Z., Zhang, B., Liu, Y., \& Lu, F. (2004). Inoculation techniques used for inducing Rice false smut efficiently. Acta Phytopathologica Sinica, 34(5), 463-467.

Zhang, S., Chen, Q., Lv, L., Yang, X., \& Yu, D. (2006). Identification of partial main cultivars' resistance to rice false smut (Ustilaginoidea virens) in Hubei province. Anhui Agri Sci Bull, 12(5), 76-78.

Zhang, X., Ye, C., Yi, K., Xie, S., \& Yang, G. (2009). Cause for rice false smut prevalent in middle-season rice and its control strategy. Modern Agri Sci and Tech, 5, 123-125. 
Zhou, Y. L., Pan, Y. J., Xie, X. W., Zhu, L. H., \& Xu, J. L. (2008). Genetic diversity of rice false smut fungus, Ustilaginoidea virens an d its pronounced differentiation of populations in North China. J Phytopathol, 156, 559-564. https://doi.org/10.1111/j.1439-0434.2008.01387.x

Zou, G., Wei, Y., \& Cheng, J. (1994). Grey relational analysis of damage and yield loss caused by rice false smut. J of Guangxi Agri Univ, 13(2), 141-143.

\section{Copyrights}

Copyright for this article is retained by the author(s), with first publication rights granted to the journal.

This is an open-access article distributed under the terms and conditions of the Creative Commons Attribution license (http://creativecommons.org/licenses/by/4.0/). 